\title{
Dermatoscopia
}

\section{MELANOMA? OBSERVE MAIS PERTO}

\author{
Mota Fl', Lobo $\mathrm{I}^{2}$, Mahia Y3, Costa $\mathrm{V}^{4}$, Selores $\mathrm{M}^{5}$ \\ 'Second year Resident in Dermatology, \\ ${ }^{2}$ Consultant, Department of Dermatology, Hospital de Santo António - CHP, Portugal \\ ${ }^{3}$ Anatomopathologist, Laboratório de Anatomia Patológica Dr. Macedo Dias, Porto, Portugal \\ ${ }^{4}$ Senior consultant, Department of Dermatology, Hospital de Santo António - CHP, Portugal \\ ${ }^{5}$ Senior Consultant, Director of the Department of Dermatology, Centro Hospitalar do Porto, Portugal \\ Dermatology Research Unit, Centro Hospitalar do Porto, Portugal \\ Instituto de Ciências Biomédicas Abel Salazar, University of Porto, Portugal
}

RESUMO - Lesões cutâneas pigmentadas por vezes são mal diagnosticadas devido às semelhanças entre as lesões melanocíticas e não-melanocíticas.

Relatamos o caso de um doente com uma lesão pigmentada, clinicamente sugestiva de melanoma. Quando analisada com dermatoscopia, é possível observar características, nomeadamente áreas "leaf-like", que nos permitem fazer o diagnóstico de carcinoma basocelular pigmentado.

Este caso representa uma situação clínica em que o exame clinico isoladamente pode levar a um diagnóstico incorreto, mas que com o apoio da dermatoscopia foi feito corretamente.

PALAVRAS-CHAVE - Carcinoma basocelular; Melanoma; Dermatoscopia.

\section{MELANOMA? LOOK CLOSER}

ABSTRACT - Pigmented skin lesions are sometimes misdiagnosed due to clinical similarities between melanocytic and non-melanocytic lesions.

We report the case of a patient with a pigmented lesion that clinically resembles melanoma. With dermoscopy, observed features, namely leaf-like areas, allowed us to make the diagnosis of pigmented basal cell carcinoma.

This case represents a clinical setting in which clinical examination alone could lead to a misdiagnosis, but with the use of dermoscopy an accurate diagnosis was possible.

KEY WORDS - Carcinoma, Basal cell; Melanoma; Dermatoscopy.

Conflitos de interesse: Os autores declaram não possuir conflitos de interesse.

No conflicts of interest.

Suporte financeiro: O presente trabalho não foi suportado por nenhum subsídio ou bolsa.

No sponsorship or scholarship granted.

Direito à privacidade e consentimento escrito / Privacy policy and informed consent: Os autores declaram que pediram consentimento ao doente para usar as imagens no artigo. The authors declare that the patient gave written informed consent for the use of its photos in this article.

Recebido/Received - Março/March 2014; Aceite/Accepted - Abril/April 2014 


\section{Dermatoscopia}

\author{
Correspondêncio \\ Dr. Fernando Mota \\ Department of Dermatology \\ Hospital de Santo António - CHP \\ Rua Central 180, Branzelo \\ 4515-498 Melres, Gondomar, Portugal \\ Tel.: 00351914529411 \\ E-mail: fernandojrmota@gmail.com
}

Pigmented lesions can be classified into melanocytic or non-melanocytic. Sometimes they are misdiagnosed due to clinical similarities.

Pigmented basal cell carcinomas (BCCs) may be mistaken especially for melanoma because of their similar clinical appearance and their differential diagnosis has a great importance when deciding treatment and prognosis'. Dermoscopy can be a helpful tool when it is difficult to distinguish pigmented BBC from melanoma and other pigmented lesions. Dermoscopic features for pigmented BCCs are more specific and sensitive facilitating the diagnosis of this tumour. The clinical pdiagnostic rate for BCC is about $60 \%$ and dermoscopy increases the diagnostic accuracy up to $90 \%{ }^{2}$.

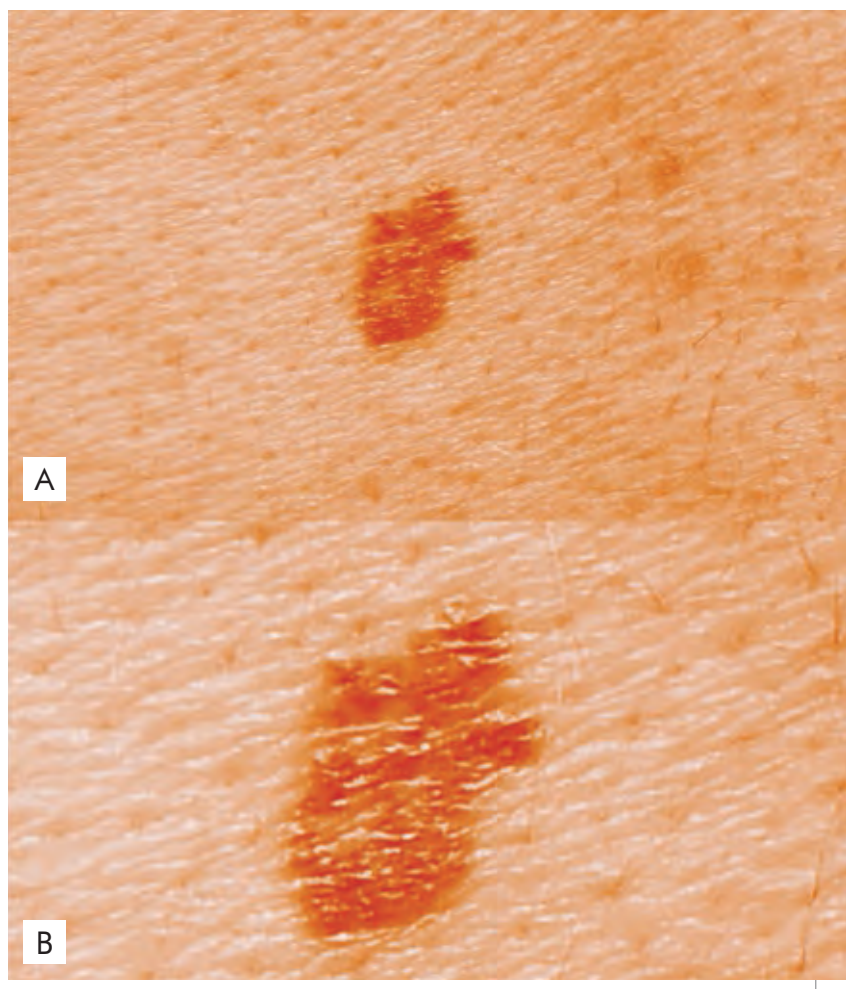

Fig. 1
We present a case of a 62 year-old man, with a prior medical history of type 2 diabetes, arterial hypertension and dyslipidemia. He had a pigmented plaque of brownish color, with $1 \times 0,5 \mathrm{~cm}$ in the lower dorsal area of the trunk for over 6 months.

Clinically, the lesion resembled a melanocytic tumour, specifically a melanoma, due to the brownish color with irregularly distributed pigment, the asymmetry and the irregular borders (Fig. 1). However, when the lesion was analyzed with dermoscopy (also known as epiluminescence microscopy, dermatoscopy, and amplified surface microscopy), it was possible to make a more accurate diagnosis based on the following features (Fig. 2): - absence of pigment network, dots, globules or streaks, which are the hallmarks of melanocytic lesions; - presence of lighter, yellow-brown areas in the edges of the lesion with brown to gray-blue discrete bulbous blobs, sometimes forming a leaf-like pattern, that correspond to pigmented epithelial nests observed on histology in the papillary dermis; - observation that the darker areas are in fact gray-blue nests and not brown, as clinically appears. These characteristics allow us to make the diagnosis of a pigmented BCC.

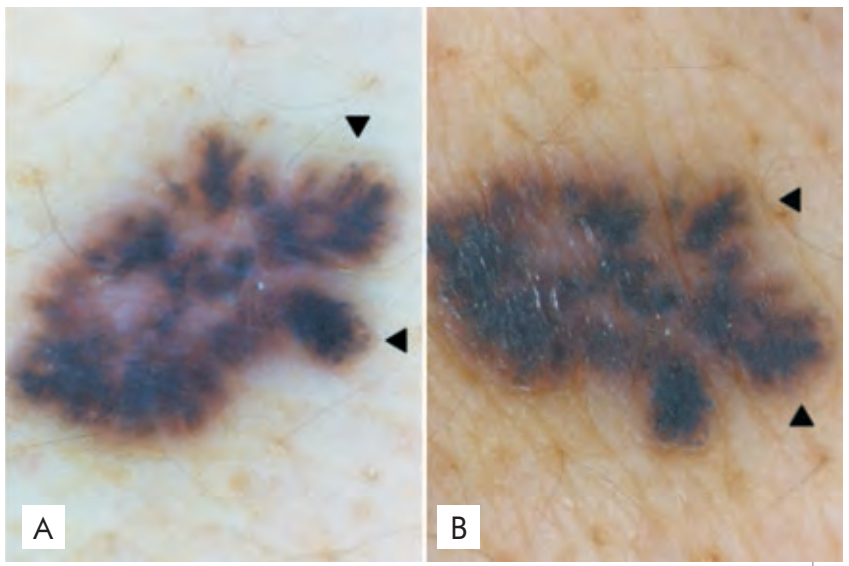

Fig. 2 


\section{Dermatoscopia}
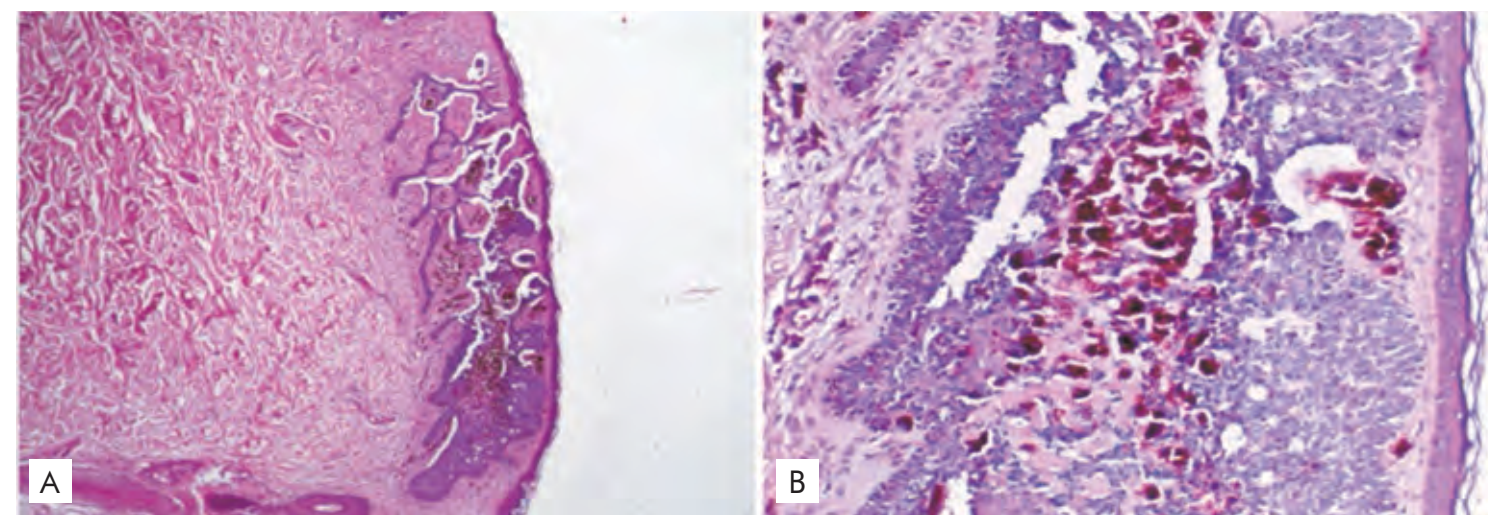

Fig. 3

Surgical excision was performed and histopathology revealed a cutaneous tumoral lesion composed by basophilic cells with peripheral palisading forming tumoral lobules in the dermis with abundant melanotic pigmentation, thus confirming the diagnosis of pigmented BCC (Fig. 3).

There are many publications dealing with the differential diagnosis of pigmented lesions of the skin. Dermoscopy allows the differentiation between melanocytic and non-melanocytic lesions according to the presence or absence of several characteristic structures: aggregated globules, pigment network, branched streaks, homogeneous blue pigmentation (blue nevus), or a parallel pattern (palms, soles, and mucosa) point to a melanocytic lesion ${ }^{3,4}$. In the absence of these structures, the lesion has to be evaluated for the presence of other features. Arborizing blood vessels (telangiectasia), leaf-like areas, large blue-gray ovoid nests, multiple blue-gray globules, spoke wheel areas, or ulceration point to the diagnosis of a $\mathrm{BCC}^{3-7}$.

Nowadays, digital dermoscopy has become more and more frequently integrated into everyday clinical practice for dermatologists. The possibility of a more accurate diagnosis, especially when analyzing a tumoral lesion, makes it a valuable instrument with a particular semiology that dermatologists should be trained for.

This case represents a clinical setting in which the clinical examination alone could lead to a misdiagnosis, but with the use of dermoscopy an accurate diagnosis was possible.

\section{REFERENCES}

1. Grant-Kels JM, Bason ET, Grin CM. The misdiagnosis of malignant melanoma. J Am Acad Dermatol. 1999; 40:539-48.

2. Steiner A, Pehamberger H, Wolff K. In vivo epiluminescence microscopy of pigmented skin lesions, II: diagnosis of small pigmented skin lesions and early detection of malignant melanom. J Am Acad Dermatol. 1987; 17:584-91.

3. Fabiano A, Argenziano G, Longo C, Moscarella E, Specchio F, Lallas A. Dermoscopy as an adjuvant tool for the diagnosis and management of basal cell carcinoma. G Ital Dermatol Venereol. 2015 Mar 9 [Epub ahead of print].

4. Puig S, Cecilia N, Malvehy J. Dermoscopic criteria and basal cell carcinoma. G Ital Dermatol Venereol. 2012; 147(2):135-40.

5. Argenziano G, Soyer HP, Chimenti S, Talamini R, Corona R, Sera F, et al. Dermoscopy of pigmented skin lesions: results of a consensus meeting via the Internet. J Am Acad Dermatol. 2003; 48:679-93.

6. Soyer HP, Argenziano G, Ruocco V, Chimenti S. Dermoscopy of pigmented skin lesions (Part II). Eur J Dermatol. 2001; 1 1:483-98.

7. Menzies SW, Westerhoff K, Rabinovitz H, Kopf AW, McCarthy WH, Katz B. Surface microscopy of pigmented basal cell carcinoma. Arch Dermatol. 2000; 136:1012-6. 